\title{
PENGARUH COMPUTER ANXIETY TERHADAP KEAHLIAN KARYAWAN DALAM MENGGUNAKAN KOMPUTER
}

\author{
Sigit Handoyo \\ Nike Ardhini Cahyono \\ Universitas Islam Indonesia
}

$A B S T R A C T$

\begin{abstract}
This study entitled "The Effect of Computer Antiet aiongside Emplores in Using Computer Skills" aims of the study is to etamination significant result betricen compurer anier and computing skill. The number of 9 - respondent emplovees as sample who working in the Lniversitas Islam Indonesia. Data collection fecitniques using questionnaires and measured using a Likert scale of measurement. The analysis rools are simple regression test. The result of this study stows that computer amiert. strong significantly toward using comptuers shills level of employee.
\end{abstract}

Kentrords: Effect of Computer Anxietn, Computer Shills

\begin{abstract}
PENDAHULUAN
Kehadiran dan pesatnya perkembangan teknologi informasi dewasa ini memberkan berbagai kemudahan pada kegiatan bisnis dalam lingkungan yang semakin penuh ketidakpastian. Peran teknologi informasi sebagai alat bantu dalam pembuatan keputusan bisnis pada berbagai fungsi maupun peringkat manajerial, menjadi semakin penting bagi pengelola bisnis karena kemampuan teknologi informasi dalam mengurangi ketidakpastian.

Berbagai hasil penelitian memberikan bukti empiris mengenai semakin meningkatnya peran teknologi komputer untuk berbagai kepentingan bisnis. Misalnya, Lavota (1990) dalam Eko \& Istiati (2005) meneliti kemampuan teknologi komputer sebagaj alat bantu dalam berbagai teknik audit.

Aplikasi komputer juga digunakan untuk peningkatan produktivitas dan pengendalian mutu produk melalui computer-aided design dan
\end{abstract}

computer-intregated manufaknting (Bennet e: al. 1987). Hasil penelitian tersebut menunjukkar bahwa teknologi komputer telah dimanfaatkar untuk berbagai kepentingan bisnis. Manfaat yang diperolch antara lain: penghematan dan ketepatar waktu, peningkatan produktivitas, dan akuras: informasi yang lebih baik. Menurut Porter (1980 pemanfatan teknologi komputer juga bertujuan untuk mencapai efisiensi atau diferensiasi produh untuk memperoleh keunggulan bersaing dan lebih berorientasi pencapaian laba dalam jangka panjang.

Penerapan teknologi menimbulkan sejumlah problematik yang berasal dari berbagai faktor, antara lain: ekonomi, teknologi, konsep sistem dan aspek perilaku. Dari berbagai faktor penyebab problematik dalam pengembangan teknologi komputer, aspek perilaku merupakan faktor yang dominan (Igbaria. 1984).

Menurut Igbaria dan Pasuraman (1989), ketidaksukaan seseorang terhadap komputer dapat disebabkan oleh ketakutan terhadap pengguna teknologi komputer atau disebut juga computer 
Fut. Penelitianiniselanjutnyamenitikberatkan zuca aspek computet anxiety sebagai refleksi was seseorang terhadap teknologi komputer.

Dalampenelitianyang dilaktkan Heinssen Z1. 1987) dalam indriantoro (2000) menyatakan ziz= a mahasiswa dengan computer anxier z whih tinggi mempunyai kepercayaan pada L- -mpuan diri sendiri dan kinerja yang lebih - aud dbanding mereka yang memiliki computer. yang lebih rendah. Dalam kaitannya jelaksanatin tugas dengan menggunakan ter, subyek dengan computer anxiety yang nggi memerlukan waktu yang lebih lama nemvelesaikan tugas tersebut dibandingkan x yang memiliki computer anxiety yang suah dalam hal penyclesaian tugas.

Penclitian ini juga pernah dilakukan oleh wayat $(2007)$ yang meneliti pengaruh antety terhadap karyawan bagian pada Bank Rakyat Indonesia Cabang di Bumiayu. apakah computer amiet - sngaruh terhadap kinerja karyawan bank. :0 (2004) juga melakukan penelitian srupa dengan menggunakan sampel at akuntansi pada perusahaan tekstil di - Penelitian sebelumnya menggunakan - Hrtyanan akuntansi dalam perusahaan 4. Surakarta, sedangkan dalam penelitian zeumakan sampel karyawan di lingkungan nas Islan Indonesia.

:EVIE W LITERATLR DAN HIPOTESIS

Fercertian Anxicty

Metrurut Macquire Dictionary, anxiery

acis Assukaran atau kesulitan berfikir yang Ecteckn oleh ketakutan pada sesuatu yang akan Exat.ms bahaya atau kemalangan. Sedangkan Etrs arciety menurut May (1997) dalam Dian 2014) dalam Eko dan Istiati (2005) adalah Eagz: suatu ketakutan pada sesuatu yang akan etu atas adanya ancaman terhadap beberapa silv yng dianggap penting oleh individu atas cerertannya sebagai seorang pribadi.
Anxiety sebagai suatu ketakutan yang berlebihan yang memotivasi keragaman perilaku. pertahanan diri, temasuk gerak - gerik jasmani, ketakutan batiniah atau kekacauan adalah gambaran yang dikemukakan oleh Levit (1967) dalam Eko dan Istiati (2005) tentang anxiery. Kumpulan defmisi dan interpretasi terhadap anxiery mengesankan bahwa tidak ada kesepahaman yang pasti mengenai difinisi anxiety. Seperti yang dingukapkan Levit (1967) mengungkapkan bahwa ruang lingkup definisi anxiety yang tepat itu tidak terbatas dan sangat luas.

\section{Computer Anxiety}

Computer anxiety menurut Igbaria dan Parasuraman (1989) adalah sebagai suatu kecenderungan seseorang menjadi susah, khawatir atau ketakutan mengenai penggunaan teknologi informasi (komputer) pada masa sekarang atau pada masa yang akan datang.

Menurut Linda V. Ort (2000), computer anxiety merupakan salah satu technophobia yang mana komputer merupakan salah satu teknologi yang berkembang dalam kehidupan manusia yang dapat menimbulkan sikap pobia bagi orang yang akan menggunakannya. Technophobia sendiri dapat digolongkan menjadi 3 tingkatan, yaitu:

a. Anxious Technophobe

Seseorang yang temasuk dalam tingkatan ini akan menunjukkan tanda-tanda klasik yang merupakan reaksi kekhawatiran (anxiery reaktion) ketika menggnakan suatu teknologi, tanda-tanda tersebut dapat berupa munculnya keringat ditelapak tangan. detak jantung yang keras atau sakit kepala.

b. Cognotive Technophobe

Seseorang yang termasuk dalam tingkatan ini pada mulanya merasa tenang dan relaks, mereka sebenamya menerima suatu teknologi baru tetapi muncul beberapa pesan negatif seperti "Saya akan menekan tombol yang salah dan mengacaukan mesin ini". 
c. Unconfortable User

Seseorang yang termasuk dalam tingkatan ini dapat dikatakan sedikit khawatir dan masih muncul pernyaraan negatif, tetapi secara umum tidak membutuhkan one-ononecounselling.

Kegelisahan dalam menggunakan komputer dapat memuneulkan dua hal. yaitu:

a. Fear (Takut)

Seseorang yang merasa takut dengan adanya komputer karena mereka belum banyak menguasai teknologi komputer, sehingga mereka belum bisa mendapatkan manfaat dengan kehadiran komputer.

b. Anicipotion (Antisipasi)

Seseorang merasa perlu melakukan antisipasi terhadap kegelisahan yang muncul dengan adanya komputer. Antisipasi tersebut dapat dilakukan dengan menerapkan ide-ide pembelajaran yang menyenangkan (anticipation) terhadap komputer.

Seseorang yang memiliki computer anxiety yangtinggi memiliki kepercayaan pada kemampuan sendiri dan kinerja yang lebih mudah dibandingkan dengan karyawan yang memiliki compnter anxien yang lebih rendah. Dalam kaitannya dengan pelaksanaan tugas dengan menggunakan komputer. seseorang dengan computer amxiety lebih tinggi memerlukan waktu yang lebih lama untuk menyelesaikan rugas tersebut dibandingkan dengan yang memiliki computer anxiety yang lebih tinggi.

\section{Pengaruh Sikap dan Computer Anxiety Terhadap Keahlian \\ Indriantoro (2000) yang melakukan} penelitian mengenai hubungan antara sikap individual pemakai dengan pemanfaatan teknologi komputer. menemukan bahwa individu yang memiliki sikap positif terhadap komputer lebih banyak menggunakan komputer dibandingkan subyek yang memiliki sikap negatif. Sikap pemakai komputer (computer antinide. menunjukkan reaksi atau penilaian seseoran terhadap komputer berdasarkan kesenangan ata ketidaksenangamya terhadan komputer. Siks pemakai terhadap komputer. dengan demikia dapat bersifat positif atau bersifat negatif yan dapat pula ditunjukkan dengan sikap optimist. pemakai bahwa komputer sangat membant dan bermanfaat untuk mengatasi masalah ata pekerjaannya. Sebaliknya, sikap dapat pul ditunjukkan dengan sikap pesimistik pemaka bahwa komputer dapat mendominasi da mengendalikan kehidupan manusia, sehingg menyebabkan pemakai merasa terintimidasi ole kompurer.

Penelitian Igbaria dan Pasuramat (1989). Webster et al. (1990), dan Igbari. (1994) dalam Indriantoro (2000) menemukat bahwa kecenderungan sescorang menjadi susah khawatir atau ketakutan terhadap kompute (computer anxien) di masa sekarang dan di mas: yang akan datang mempunyai pengaruh yan negatif terhadap sikap pemakai dengan teknolog komputer. Oleh karena sikap negatif pemaka mengakibatkan rendahnya tingkat keahlia: dalam penggunaan komputer, tingginya compute: anxiet mempunyai pengaruh negatif terhada keahlian yang bersangkutan dalam menggunakat komputer.

Penelitian ini memberikan perhatiai terhadap aspek perilaku pemakai secara individua yang diproksikan dengan tingkat compute. anxien-nya dan pengaruhnya terhadap kinerj: individual yang diproksikan dengan keahlia: pemakai dalam menggunakan komputer. Gamba 1 berikut menyajikan nodel kerangka pemikirai yang menguji pengarth computer anxiety terhadal keahlian pemakai dalam penggunaan komputer,

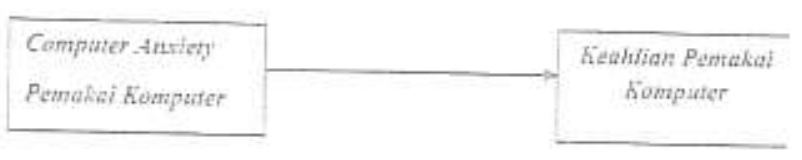

Gambar 1

Model Penelitian 
Etahlian Menggunakan Komputer

Harrison dan Rainer (1992) dalam Astuti Jalam Eko \& Istiati (2005) mendefinisikan an sebagai berikut:

"Keahlian adalah suatu perkiraan atas kemampuan seorang untuk melaksanaskerjaan dengan sukses, seorang yang megu-sgap dirinya mampu untuk melaksanakan zas, cenderung akan sukses".

Sedangkan dalam Igbaria (1994) dalam text 2003) dalam Eko \& lstiati (2005) keahlian zengeunakan komputer menurut didefinisikan schezi berikut:

Keahlian menggunakan komputer adauatu kombinasi antara pengalaman user da- menggunakan komputer. latihan yang telah oh dan keahlian komputer secara menye-

Penerimaan teknologi komputer dipengaoleh teknologi itu sendiri serta tingkat an dari individu yang menggunakan urzater. Keyakinan bahwa setiap orang dapat ter-ikatkan keahliannya sangat diperlukan, ze-na untuk keefektifan penggunaan komputer - menguatkan rasa percaya diri setiap orang mu-pu menguasai dan menggunakan teknologi - - uter dalam pekerjaannya adalah menurut 12... (2003) dalam Eko \& Istiati (2005).

\section{Bipotesis}

Hubungan antara compter anxien dengan wahian menggunakan komputer dalam kerangka - - ktran ini digambarkan bahwa computer 20.ta) mempunyai pengaruh negatif terhadap etalian komputer, Pemakai komputer dengan atter anxiety yang rendah akan menunjukkan - zar keahlian menggunakan komputer yang atunggi. Sedangkan pemakaikomputer dengan aryuter anxient yang tinggi akan menunjukkan * kat keahlian menggunakan komputer yang whih rendah

Hubungan variabel computer anxiety E- Keahlian komputer dalam penelitian ini. wtasarkan penelitian-penelitian sebelumnya dihipotesiskan bahwa pemakai komputer dengan computer anxiery yang lebih rendah menunjukkan tingkat keahlian komputer yang lebih tinggi daripada pemakai komputer yang mempunyai computer anviety yang lebih tinggi. Hipotesis yang akan diuji secara empiris dalam penelitian ini dinyatakan dengan rumusan sebagai berikut:

Ha: Computer anxiety mempunyai pengaruh negatif terhadap keahlian karyawan dalam menggunakan komputer.

\section{METODE PENELITIAN}

Subjek Penelitian dan Pengumpulan Data

Populasi dari penelitian ini adalah karyawan pada lingkungan Universitas Islam Indonesia. Metode pengambilan sampel yang digunakan adalah random sampling. Sampel yang diambil adalah karyawan Lniversitas Islam Indonesia yang secara tidak sengaja bertemu dengan peneliti. Dengan kata lain sampel diambil/ terpilih karena ada ditempat dan waktu yang tepat. Tanpa kriteria peneliti bebas memilih siapa saja yang ditemuinya untuk dijadikan sampel karena semua pekerjaan yang dilakukan oleh para pegawai di lingkungan Universitas Islam Indonesia dengan menggunakan komputer.

Dari segi rekonstruksi pertanyaan, penelitian ini menggunakan kuisioner dengan pertanyaan terbuka maupun tertutup, serta bersifat umum, guna memperoleh data yang menyangkut identitas resonden. Apabila alat yang digunakan dalam proses data tidak valid atau kurang dapat dipercaya, maka hasil penelitian yang diperoleh tidak akan mampu menggambarkan keadaan sesungguhnya. Untuk itu dipertukan pengujian seberapa baik instrumen yang digunakan, maka perlu dilakukan uji reliabilitas dan uji validitas.

Kuisioner dibagi dalam 2 kategori pertanyaan yaitu :

1. Variabel Independen yaitu tentang computer amiety

2. Variabel Dependen yaitu keahlian dalam menggunakan komputer. 
Keseiuruhan item tersebut menggunakan skala likert $1-5$, nilai satu menunjukkan sangat tidak setuju, nilai lima menunjukkan sangat setuju. Instrumen yang dipakai dalam variabel tersebut dikatakan reliabel apabila memiliki Cronbach s.tipha $>0$.6. Dalam penelitian ini, uji validitas dilakukan dengan membandingkan nilai corrected item - total correlation dengan nilai $r$ tabel. Jika CI - TC > r tabel. maka butir pada kuisioner tersebut dapat dikategorikan valid.

\section{Metode Analisis Data}

Analisis data dalam penelitian ini menggunakan metode statistik regresi sederhana dengan bantuan program SPSS. Metode ini merupakan alat analisis statistik untuk menguji hubungan antara varjabel independen dan variabel dependen.

Fonmulasi model persamaan regresi penelitian ini adulah:

$$
Y=\alpha+\beta, x
$$

Dimana:

Y = Variabel dari keahlian dalam penggunaan komputer

$\alpha \quad=$ Konstanta $(0)$

Bi $=$ Kemiringan (slope) kurva Tinier

$\mathrm{Xi}=$ Variabel dari computer anxiery

Variabel independen (computer anxiety) diekspektasikan akan mempengaruhi variabel dependennya (kcahlian komputer). Jika koefisien $\beta$ negatif dan signifikan, berarti semakin tinggi keahlian dalam menggunakan komputer. Atau sebaliknya, semakin tinggi computer anxiety pemakai maka semakin rendah keahlian dalam menggunakan komputer.

Pengaruh variabel independen terhadap variabel dependen akan diuji dengan tingkat signifikasi $p \leq 0.05$. Jika koefisien $\beta$ positif dan signifikan maka hipotesis penelitian ditolak, begitupun sebaliknya. Hasil penelitian ini mendukung hipotesis yang menyatakan bahw computer amxien mempunyai pengaruh negat terhadap keahlian karyawan dalam menggunake komputer.

\section{HASIL PENELITIAN DAN PEMBAHASA}

Dalam penelitian ini jumlah karyawa tetap untuk semua fakultas berjumlah 196 orar dan dalam tabel (Sumanto, 1995) didapat bahw untuk populasi antara 190-200 maka sam minimalnya sebesar antara 127-132 orang.

Pengumpulan data tersebut dapat dilit pada tabel 1 , dari 120 kuisioner yang dises terdapat 97 data jawaban responden yamemenuhi syarat dalam penelitian.

Tabel 1

Cara Perolehan Responden

\begin{tabular}{|c|c|c|c|c|}
\hline \multirow{2}{*}{\multicolumn{4}{|c|}{ Kuisioner vang didistribustkan }} & \\
\hline & & & & 20 lembat \\
\hline \multicolumn{4}{|c|}{ Kulsioner vang tadak kembalt } & 23 lembar \\
\hline \multicolumn{4}{|c|}{ Tol1 kulsioner vane dirssoon } & 7) lembar \\
\hline \multicolumn{4}{|c|}{ Tidak lengkap } & - \\
\hline \multicolumn{4}{|c|}{ Ditsi sembarangan } & 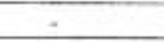 \\
\hline \multicolumn{4}{|c|}{ Kriteria responden tidak serpenulit } & 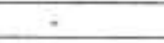 \\
\hline \multicolumn{4}{|c|}{ Total kuistoner yang tidak dinergunakan } & - \\
\hline \multicolumn{4}{|c|}{ Total kuisionet vane dipcrountikan } & 97 lembar \\
\hline \multicolumn{5}{|c|}{ Sumber : hasil olah data } \\
\hline \multicolumn{5}{|c|}{$\begin{array}{l}\text { Setelah dilakukan tabulasi terhadap } \\
\text { kuisionertersebut,penulisdapatmengelompokka } \\
\text { responden berdasarkan umur. jenis kelami } \\
\text { pendidikan, dan pengalaman dengan komput } \\
\text { yang ditunjukkan dalam tabel-tabel berikut ini. }\end{array}$} \\
\hline \multirow{2}{*}{\multicolumn{5}{|c|}{$\begin{array}{c}\text { Tabel } 2 \\
\text { Jenis Kelamin Responden }\end{array}$}} \\
\hline & & & & \\
\hline & Erequency & Percent & $\begin{array}{l}\text { Valid } \\
\text { Percent }\end{array}$ & $\begin{array}{l}\text { Cumulative } \\
\text { Percent }\end{array}$ \\
\hline Vialid Pria & 63 & $5+9$ & 64,9 & 64.9 \\
\hline Winita & 34 & 35.1 & 35.1 & \\
\hline Tota! & 97 & 100.0 & 100.0 & 100.0 \\
\hline
\end{tabular}

Sumber : hasil oialt data

Berdasarkan tabel diatas diketahui bahw persentase responden pria lebih besar daripad wanita yairu sebesar $64.9 \%$. 
Tabel 3

Usia responden

\begin{tabular}{|c|c|c|c|c|}
\hline & Frequenzy & Percen: & $\begin{array}{l}\text { Valted } \\
\text { Persent }\end{array}$ & $\begin{array}{l}\text { Curtulative } \\
\text { Percent }\end{array}$ \\
\hline A= V.. thus & 17 & 105 & 175 & $1^{4}=$ \\
\hline$x-2 y$ thith & 3. & 320 & 32.0 & \\
\hline A E thitut & 36 & 37.1 & 37.1 & 49.5 \\
\hline 5. tafinut & 13 & 134 & 13.4 & 86.6 \\
\hline$=$ & $9=$ & 100.0 & 100.0 & \\
\hline
\end{tabular}

Berdasarkan tabel diatas dapat diketahui

tesponden penelitian ini terdiri dari tingkatan umur. yaitu dibawah 30 tahun diatas 50 tahun. Unur responden yang szing muncul adalah umur yang berkisar 2.:- 4 sampai 50 tahun yaitu sebesar 36 $=$

Tabel 4

Tingkat Pendidikan Responden

\begin{tabular}{|c|c|c|c|c|}
\hline & Freguency & Percent & $\begin{array}{l}\text { Valid } \\
\text { Percent }\end{array}$ & $\begin{array}{c}\text { Cumulanive } \\
\text { Percent }\end{array}$ \\
\hline 1285 & - & & & \\
\hline si & 26 & 26.8 & 26.8 & 26.8 \\
\hline 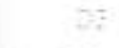 & 30 & 31.0 & 31.0 & 57.8 \\
\hline 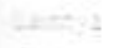 & 4 & $+2: 2$ & 42.2 & \\
\hline- & 97 & 100.0 & 100.0 & 100.0 \\
\hline
\end{tabular}

-asit olah data

Berdasarkan tabel diatas responden dapat 4i. dari latar belakang tingkat pendidikan berbeda, yaitu SMU atau sederajat - Zidikan laimya) sampai dengan tingkat S2. - gka: pendidikan responden yang paling sering _-...ladalah tingkat pendidikan SMU (lainnya), - zebesar 41 orang.

Tabel 5

Pengalaman Menggunakan Komputer

\begin{tabular}{|c|c|c|c|c|}
\hline & Frequency & Percent & $\begin{array}{l}\text { Valid } \\
\text { Percent }\end{array}$ & $\begin{array}{c}\text { Cumulative } \\
\text { Percenr }\end{array}$ \\
\hline as a whon & 18 & 18.5 & 18.5 & \\
\hline f $\varepsilon$ uftun & 29 & 30.0 & 30,0 & \\
\hline 5 : ahum & 50 & $5 ! 5$ & $5 ! .5$ & 48.5 \\
\hline$-x+i$ & $9=$ & 1000 & 100,0 & 100,0 \\
\hline
\end{tabular}

hasit olah data
Responden dilihat dari berbagai tingkatan pengalaman menggunakan komputer, pada tabel dapat diketahui bahwa pengalaman responden yang paling sering muncul adalah pengalaman responden dalam menggunakan komputer yaitu lebih dari 5 tahun sebesar $51.5 \%$.

\section{Statistik Deskriptif}

Ada dua variabel pokok yang diukur dan dianalisis dalam penelitian ini, yaitu computer anxiety dan keahlian dalam menggunakan komputer. Berikut ini uraian mengenai statistik deskriptif yang menjelaskan secara global skor jawaban responden, yang terdiri dari rata-rata dan deviasi standar. Untuk lebih jelasnya dapat dilihat di tabel berikut :

Tabel 6

\begin{tabular}{|c|c|c|c|}
\hline \multicolumn{4}{|c|}{ Descriptive Statistic } \\
\hline & $\mathrm{N}$ & Mean & Std. Deviation \\
\hline Computer thrier: & 97 & & \\
Keahlian menggunakan & 97 & 2.5113 & $\$ 5093$ \\
computer & & 4.1233 & 43195 \\
\hline
\end{tabular}

Sumber : hasit olah data

Dari tabel diatas dapat dijelaskan bahwa untuk variabel computer anxiety $(\mathrm{X})$, diperoleh nilai mean yaitu sebesar 2.5113 . Demikian juga diketahui standar deviasi yaitu untuk mengetahui seberapa besar penyimpangan data dengan nilai rata - rata hitungnya, dari tabel diatas penyebaran data untuk 97 responden yaitu 0.50993 untuk variabel computer anxiery dan 0.43195 untuk variabel keahlian dalam menggunakan komputer.

\section{Uji Validitas dan Reliabilitas}

Uji validitas digunakan untuk menguji sejauh mana ketepatan alat ukur dapat mengungkapkan konsep gejala / kejadian yang diukur. Pengujian validitas dilakukan dengan menggunakan analisis korelasi product moment yang terkoreksi (corrected item-total comelation). Penggunaan nilai corrected item- 
total correlation digunakan karena nilai tersebut sudah menghilangkan bias ukuran yang diperoleh dari uji korelasi product momen biasa. Nilai uji validitas dengan corrected item-total correlation ditunjukkan pada kolom corrected item-total correlation dari hasil pengujian dengan bantuan SPSS. Berikut ringkasan hasil pengujian validitas tersaji dalam tabel berikut :

\section{Uji Validitas}

Tabel 7

Ringkasan Hasil Pengujian Computer Anxiety

\begin{tabular}{|c|c|c|c|}
\hline $\begin{array}{l}\text { Yariabel } \\
\text { Computer } \\
\text { Anxiety }\end{array}$ & $\begin{array}{c}\text { Korelasi } \\
\text { (rxy) }\end{array}$ & rTabel & Keterangan \\
\hline $\mathrm{Pl}$ & 358 & .199 & Tallid \\
\hline $\mathrm{P} 2$ & .368 & 199 & Valid \\
\hline P3 & 345 & 199 & Malid \\
\hline$P_{4}$ & 461 & 190 & Vatid \\
\hline P5 & .302 & 199 & Vald \\
\hline P6 & 625 & .199 & Valid \\
\hline P7 & 433 & .199 & Balid \\
\hline P8 & .584 & .199 & Valid \\
\hline$P 9$ & 421 & 199 & Valid \\
\hline $\mathrm{P} 10$ & 372 & .199 & Valid \\
\hline $\mathrm{P} 11$ & 465 & .199 & Valid \\
\hline $\mathrm{P} 12$ & 426 & 199 & Valid \\
\hline $\mathrm{P} 13$ & 381 & .199 & Valicl \\
\hline $\mathrm{P} 14$ & .552 & 199 & Valid \\
\hline P15 & .536 & .199 & Valid \\
\hline Ple & 478 & 199 & Yalid \\
\hline P17 & .376 & .199 & Valid \\
\hline 218 & .565 & .199 & Valid \\
\hline$P 19$ & 333 & 199 & Valid \\
\hline
\end{tabular}

Sumber: hasil olah data

Berdasarkan tabel perhitungan diatas. dapat diketahui nilai korelasi dari seluruh butir pertanyaan tentang computer anxiety. Dari hasil perhitungan koefisien korelasi (rxy) seluruhnya mempunyai $r$ hitung yang lebih besar dari $r$ tabel ( $\mathrm{r}$ tabel $=0.199)$, maka seluruh butir pertanyaan tentang computer anxiety pada kuisioner adalah valid.
Tabel 8

Ringkasan Hasil Pengujian Keahlian Dalam Menggunakan Komputer

\begin{tabular}{|c|c|c|c|}
\hline $\begin{array}{c}\text { Variabel Keahlian } \\
\text { Dalam Menggunakan } \\
\text { Komputer }\end{array}$ & $\mathrm{R}$ & rTiabel & Keterangan \\
\hline P1 & 693 & 199 & Yalid \\
\hline $\mathrm{P2}$ & 740 & 199 & Valid \\
\hline P3 & .562 & 199 & Valid \\
\hline $\mathrm{P} 4$ & 558 & 199 & Valid \\
\hline P5 & 691 & 199 & Valid \\
\hline$P 5$ & .610 & 199 & Valid \\
\hline P7 & 668 & 199 & Valid \\
\hline P8 & .658 & 199 & Valid \\
\hline P9. & 591 & 199 & Valid \\
\hline $\mathrm{P} 10$ & .730 & 199 & Valtd \\
\hline $\mathrm{P} 11$ & 715 & 199 & Valid \\
\hline P12 & .288 & 199 & Valid \\
\hline
\end{tabular}

Sumber : hasil olah data

Berdasarkan tabel perhitungan diata dapat diketahui nilai korelasi dari seluruh but pertanyaan tentang keahlian dalam menggunaka komputer. Dari hasil perhitungan koefisie korelasi (rxy) seluruhnya mempunyai $r$ hitur yang lebih besar dart $\mathrm{r}$ tabel $(\mathrm{r}$ tabel $=0.199$ maka seluruh butit pertanyaan tentang keahlia dalam menggunakan komputer pada kuision adalah valid.

Walaupun secara statistik tidak dap dibuktikan valid atau tidak, akan tetapi seca kualitatif pertanyaan ini dapat dinyataka valid, karena sudah pernah dipergunakan dala penelitian sebelumnya. Dengan demikian dap disimpulkan bahwa, seluruh butir pertanya yang terdapat dalam kuisioner dapat dinyatake layak sebagai instrumen untuk mengukur da penelitian.

\section{Uji Reliabilitas}

Dalam penguian ini dilakukan dengs uji statistik Cronbach's Alpha. Suatu variab dikatakan reliabel jika memberikan nil Cronbach's Alpha $>0.6$ (Ghozali. 2005). Hasil reliabilitas pertanyaan tentang computer anxie dan keahlian dalam menggunakan komput dapat dilihat sebagaimana tersaji dalam tab berikut ini : 
Tabel 9

Ringhasan Hasil Pengujian Reliabilitas

\begin{tabular}{|c|c|c|}
\hline Wriabel & $\begin{array}{c}\text { Koefisien Alpha } \\
\text { Cronbach }\end{array}$ & Keterangan \\
\hline trutrity & 849 & Reliabel \\
\hline & $8 \times 8$ & Reliabel \\
\hline
\end{tabular}

sursu olah data

Betfasarkan ringkasan hasil uji reliabilitas ang terangkum dalam tabel diatas, dapat En bahwa nilaikoefisien Cronbach s Alpha Tame tong-masing variabel lainnya $>0.6$ maka - trabel penelitian adalah handal. Sehingga z... sur pertanyaan dalam variabel penelitian - ces.: dapat digunakan untuk penelitian $x=$ simya.

Walaupun secara statistik tidak dapat at-k+kin reliabel atau tidak, akan tetapi secara - pertanyaan ini dapat dinyatakan =.... Sartna sudah pernah dipergunakan dalam ze wan sebelumnya. Seluruh variabel ini dapat an susan reliabel karena koefisien alpha $>0.6$, - 2 jagat disimpulkan bahwa butir pertanyaan -u- suisioner dinyatakan layak sebagai a.man untuk mengukur data penelitian.

ESIL PENELITIAY DAN PEMBAHASAN

Crtuk mempermudah perhitungan a.. dari data yang cukup banyak maka ztan ini diselesaikan dengan bantuan nemest lunak komputer program SPSS. Hasil Z z..th terhadap model regresi sederhana - wan variabel computer anxiety $(X)$ yang - sagaruhi keahlian karyawan dalam - zo-nakan komputer dapat dilihat dalam tabel wet:
Tabel 10

Hasil Analisis Regresi

\begin{tabular}{|c|c|c|c|}
\hline $\begin{array}{c}\text { Variabel } \\
\text { Independen }\end{array}$ & $\begin{array}{c}\text { Koefisien } \\
\text { Regresi }\end{array}$ & t-hitung & Probabilitas \\
\hline Konstanta & -72 & 22501 &, 000 \\
\hline Computer Antiett & -.258 & -3.419 & .002 \\
\hline $\mathrm{R}^{2}$ & 0.93 & & \\
\hline Mulfiple $\mathrm{R}$ & 0.83 & & \\
\hline
\end{tabular}

Sumber : hasil olah data

Hasil analisis regresi secara keseluruhan menunjukkan R kuadrat (koefisien determinasi) sebesar 0.93 . Berarti ada pengaruh yang signifikan antara computer anxiery (variabel independen) tethadap tingkat keahlian dalam menggunakan komputer (variabel dependen).

Pada penelitian ini digunakan model persamaan regresi sedehana sebagai berikut:

$$
Y=\alpha+\beta_{1} x_{i}
$$

Dengan memperhatikan model regresi maka didapat persamaan pengaruh computer anxiety terhadap kehlian karyawan dalam menggunakan komputer sebagai berikut :

$$
\mathrm{Y}=4.772-0.258
$$

Koefisien $\beta$ negatif sebesar 0.258 dengan tingkat signifkansi 0.002 ( $\mathrm{p} \leq 0.005$ ). Hal ini berarti semakin rendah tingkat computer anxiety pemakai, mempunyai pengaruh semakin tingginya keahlian pemakai dalam menggunakan komputer. Atau sebaliknya, semakin tinggi computer anxiety seseorang maka akan semakin rendah tingkat keahlian dalam menggunakan komputer.

Hasil penelitian terhadap karyawan di lingkungan Unversitas Islam Indonesia konsisten dengan temuan penelitian Harrison dan Rainer (1992). Sabnerwal dan Elam (1995), Rifa dan Gudono (1999), Indriantoro (2000), Sudaryono (2004), Yunita (2004), Eko Arif dan Istiati Diah (2005), Nur Hidayat (2007) dan Pushpasari Nur Rizky (2008) yang menguji pengaruh computer anxiery terhadap keahlian dalam menggunakan komputer, menyatakan bahwa computer anxiety mempunyai hubungan negatif yang signifikan terhadap keahlian dalam menggunakan komputer. 
Hasil clari penelitian karyawan di lingkungan Universitas Islam Indonesia memiliki computer anxiefy yang rendah juga menunjukkan bahwa karyawan mempunyai kepercayaan bahwa teknologi komputer tidak mendominasi atau mengendalikan kehiduan manusia, sehingga akan menimbulkan keinginan yang kuat untuk mempelajari pemanfaatan teknologi komputer. Oleh karenanya, pemakai dengan computer antiety yang tendah akan menyebabkan tingkat keahliannya dalam menggunakan komputer relatiflebih tinggi dibandingkan yang mempunyai tingkar computer anxieny yang tinggi.

Sikap pemakai komputer terdiri dari tiga komponen kognisi. afeksi, dan keinginan. Pemakai vang mempunyai kognisi atau keyakinan bahwa teknologi komputer akan memberikan manfaat bagi dirinya dan menimbulkan afeksi yang mempunyai konotasi suka untuk menerima kehadiran komputer. Keyakinan dan afeksi yang menunjukkan sikap optimistik bahwa komputer dapat membantu mengatasi masalah dalam pekeriaannya sehingga seseorang merasa senang bekerja dengan komputer. Seseorang yang mempunyai sikap demikian tidak merasa terintimidasi. khawatir. susah atau ketakutan oleh kehadiran teknologi komputer atau mempunyai computer anxiery yang rendah.

\section{KESIMPULAN DAN SARAN}

Tujuan dari penelitian ini adalah untuk mengetahui apakah computer anxiety berpengarth signifikan terhadap keahlian dalam menggunakan komputer. Dari hasil analisis regresi sederhana menghasilkan $R^{2}$ (koefisien determinasi) sebesar 0.93 , berarti ada pengaruh yang signifikan antara computer anxiety (variabel independen) terhadap keahlian dalam menggunakan komputer (variabel dependen) dengan variasi perubahan tingkat keahlian komputer dijelaskan oleh variabel computer anxiet, sebesar $93 \%$, sedangkan sebesar $7 \%$ oleh variabel lainnya.
Koefisien regresi $(\beta)$ bemilai negati sebesar 0.258 dan thitung sebesar 3.119 dengar tingkat signifikansi 0.002 atau kurang dar 0.05 , berarti semakin rendah computer anxiet pemakai mempunyai pengaruti dengan semaki: tinggi keahlian pemakai dalam menggunakakomputer, atau sebaliknya yaitu semakin tingg compuer ansien pemakai mempunyai pengarut dengan semakin rendah keahlian pemakai dalam menggunakan komputer.

Hasil penelitian terhadap karyawar di lingkungan Universitas Islam Indonesia konsisten dengan penelitian terdahulu yang menguji pengaruh computel anxiery terhada: keahlian dalam. menggunakan komputer Computer anxien mempunyai pengaruh negatit terhadap keahlian seseorang dalam menggunaka: komputer. Implikasi dari penelitian ini adalah karyawan dapat meningkatkan keahlian mereka dalam menggunakan komputer dalam rangka meningkatkan kinerja mereka, oleh karenanya Universitas Islam Indonesia diharapkan memberikan pelatihan kepada karyawan.agar kemampuan karyawan dalam menggunakan computer meningkat sehingga kinerja juga meningkat

\section{DAFTAR PUSTAKA}

Astuti. Annisa Prima,2003. Pengarih Dukungan Organisasi Terhadap Hubungan Computer Anxiety Dengan Keahlian Auditor Menggunakan Teknik Audit Berbantuan Komputer.Skripsi S-1 UNS (tidak dipublikasikan).Fakultas Ekonomi UNS.

Djarwanto. PS..2001..Mengenal Beberapa Uji Statistik dalam Penelitian. Yogyakarta: BPFE.

Ghozali, Imam.2005.Aplikasi Analisis Multivartate Dengan Progran SPSS,Edisi Ketiga,Badan Penerbit Universitas Diponegoro,Semarang. 
the-1.2007.Pengarlih Computer Anxiery wadip Keahian Kananan Bagian thations dalam Menggunakan Xompurer.Skripsi S-1 UTl.Fakultas Exomomi Yogyakarta.(Studi pada Bank Retwat Indonesia Cabang dan unit di Bumiayu).

nutemo. Nur. 2000."Pengaruh Computer Anxiety teriadap Kealilian Dosen dalam Penggunaan Komputer" Jumal thintansi \& Anditing Indonesia, Vol.4. No. 2 Desember: 191-120.

\&-71. N \& Parasuraman. S.1989." A Path Analytic Study of Individual Characteristic, Computer Anxiety, and Attimdes Toward Microcomputer",Jumal of Management Vol.15.No.3.

- Aintoro, Nur, 1996. Sistem Informasi Strategik: Dampak Teknologi Informasi terhadap Organisasi dan Ketnggulan Komperitif. Jumal KOMPAK.No.9,Februari

cos, V.On: 2000. Computer Anxiety, University of Southern Maine.

As.sun. Zainuri.2008,"Pengaruh Faktor. Personality terfadap Reahlian dalam Pengoperasian Software SAP*'Skripsi S-1 UTI.Fakultas Ekonomi Yogyakarta.

Pusphasari,2008.Pengartu Computer Anxiety lerhadap Keahlian Karyawan Bagian Aktmansi dan Perbekalan Universitas Islam Indonesia dalam Mengoperastian S.AP.Skripsi S-1 UII. Fakuitas Ekonomi Yogyakarta.
Rifa. Dandes \& Gudono,1999,Pengaruh Faktor Demografi dan Personality terhadap Keahlian dalam End-User Computing.Junal Riset Akuntansi Indonesia. Vol No.1 Januari.20-36.

Sabherwal, Rajiv dan Elam. Joice., 1995. "Overcoming the problems in Information Systems Development by Building and Sustaining commitment". Jumal of Accounting, Management \& Information Technology, Vol. V, No. $3 / 4$.

Sudaryono. Eko Arief, 2004,Penganth Tingkat Computer Anxiety Terhadap Keahlian Dosen Akuniansi Dalam Menggmakan Komputer.Laporan Penelitian UNS (tidak dipublikasikan).Fkultas Ekonomi UNS.

Sudaryono, Eko Arif \& Istiati.,2005.Pengaruh Computer Anxiety terhadap Keahlian karyawan Bagian Akuntansi Dalam Menggunakan Komputer. (Survei pada perusahaan tekstil di Surakarta),SNA VIII.Solo.

Susilowati, Indah,2004.Pengaruh Computer Anxiety Terhadap Keahlian dalam Penggunaan Komputer; Skripsi S-1 UII. Fakultas Ekonomi UII.

Yunita. Dian, 2004. Pengaruh Tingkat Computes. Anxiety Terhadap Keahlian Dosen Akintansi Dalam Menggunakan Komputer: Skripsi S-1 UNS (tidak dipublikasikan).Fakultas Ekonomi UNS. 